\title{
PENGEMBANGAN PANGAN LOKAL MELALUI PEMBUATAN “DOKUN" (DONAT SUKUN) ANEKA TOPING DI DESA TANJUNGHARJO, NANGGULAN, KULONPROGO
}

\author{
Agus Setiyoko ${ }^{1}$, Agus Slamet ${ }^{1}$ \\ ${ }^{1)}$ Dosen Program Studi Teknologi Hasil Pertanian, Universitas Mercu Buana \\ Yogyakarta \\ Email: agus_setiyoko@mercubuana-yogya.ac.id
}

\begin{abstract}
Tanjungharjo Village, Nanggulan, Kulonprogo, has wide variety of agricultural products that has not been processed optimally. One example is breadfruit. The cultivation and development of this breadfruit has been started by the government of Special District of Yogyakarta since 2003. With several ways of processing, breadfruit fruits can be used to support food diversification. The Successful of development and diversification of breadfruit processing into region's food can increase its selling value so that impact on improving public welfare. Klajuran is one Hamlet of Tanjungharjo Village, has 'Kelompok Wanita Tani (KWT) Ngudi Makmur' with 25 members joining. This group is usually processing breadfruit using the traditional ways by steaming or friying, but the product is not so acceptable by the community. One of the factors causing the lack of processing of these products is the lack of knowledge about the various ways of processing, packaging technology and financial management in producing various foods from breadfruit as business opportunity. Based on the description, the research and community service institutions of Mercu Buana University of Yogyakarta has provided counseling and training on the processing of breadfruit's donut cake, packaging and financial management to increase the economic income of the group members.
\end{abstract}

Keywords: Bredfruit, donut cake, counseling, training, production 


\begin{abstract}
ABSTRAK
Desa Tanjungharjo, Nanggulan, Kulonprogo, memiliki beragam produk pertanian yang belum diolah secara optimal. Salah satu contohnya adalah buah sukun. Budidaya dan pengembangan buah sukun ini telah dimulai oleh pemerintah Daerah Istimewa Yogyakarta sejak tahun 2003. Dengan beberapa cara pengolahan, buah sukun dapat digunakan untuk mendukung diversifikasi pangan. Keberhasilan pengembangan dan diversifikasi pengolahan buah sukun menjadi makanan daerah dapat meningkatkan nilai jualnya sehingga berdampak pada peningkatan kesejahteraan masyarakat. Klajuran adalah salah satu dusun di Desa Tanjungharjo, memiliki kelompok wanita tani (KWT) Ngudi Makmur dengan 25 orang anggota. Kelompok ini biasanya mengolah sukun menggunakan cara tradisional dengan cara mengukus atau menggoreng, namun cara pengolahan produk seperti ini tidak begitu diterima oleh masyarakat. Salah satu faktor penyebab minimnya pengolahan produk ini adalah kurangnya pengetahuan tentang berbagai cara pengolahan, teknologi kemasan dan manajemen keuangan dalam memproduksi berbagai makanan dari sukun sebagai peluang bisnis. Berdasarkan uraian tersebut, lembaga penelitian dan pengabdian kepada masyarakat Universitas Mercu Buana Yogyakarta telah memberikan penyuluhan dan pelatihan pengolahan kue donat, pengemasan dan manajemen keuangan untuk meningkatkan pendapatan ekonomi anggota kelompok
\end{abstract}

Kata kunci: Buah sukun, kue donat, penyuluhan, pelatihan, produksi 


\section{PENDAHULUAN}

Desa Tanjungharjo terletak di Kecamatan Nanggulan, Kabupaten Kulon progo, Daerah Istimewa Yogyakarta, berjarak $15 \mathrm{Km}$ dari Kampus Universitas Mercu Buana Yogyakarta. Desa Tanjungharjo merupakan salah satu dari 6 Desa yang berada di Kecamatan Nanggulan, terdiri dari 8 dusun. Jumlah penduduk di Desa Tanjungharjo adalah 2.5076 jiwa yang terdiri dari 2.273 orang laki-laki dan 2.353 orang perempuan. Mata pencaharian adalah pada sektor prtanian sebanyak 1.448 orang, buruh 131 orang , wirasuwasta 379 orang dan pengangguran 176 orang (BPS, 2016). Salah satu hasil pertanian lahan kering di Kabupaten Kulon progo adalah buah sukun. Menurut Djaafar (2004) di Kabupaten Kulon progo telah dikembangkan hutan cadangan pangan dengan melakukan penanaman tanaman sukun pada tahun 200-2001. Buah sukun yang dipanen di Daerah istimewa yogyakarta memiliki berat sebesar 1-1,5 kg/buah dan jumlah buah dalam satu kali pemanenan kurang lebih 50 buah/pohon. Kabupaten Kulon progo memiliki populasi pohon sukun sebesar 63.657 dengan jumlah tanaman menghasilkan sebanyak 15.057 pohon dan produksinya sebesar 82,29 $\mathrm{kg} /$ pohon. Hasil panen buah sukun di Kulon Progo tidak ada yang dijual ke industri pengolahan. Berdasarkan data yang diperoleh dari Dinas Pertanian, dari 34 kelompok industri rumah tangga di Daerah Istimewa Yogyakarta tidak ada yang memproduksi buah sukun sebagai salah satu peluang usaha. Salah satu cara yang dapat dilakukan untuk menambah nilai jual produk pangan lokal adalah dengan melakukan pengolahan dan pengembangan usaha kuliner dan makanan khas dari asli daerah.

Buah Sukun mempunyai komposisi gizi yang relatif tinggi. Buah sukun mengandung kadar karbohidrat $35,5 \%$, kadar protein $0,1 \%$, kadar lemak 0,2\%, kadar abu 1,21\%, kadar fosfor $35,5 \%$, kadar protein $0,1 \%$, kandungan kalsium 0,21\%, kandungan besi $0,0026 \%$, kandungan serat atau fiber $2 \%$, serta kadar air 61,8\% dalam $100 \mathrm{~g}$ 
berat basah. Buah sukun yang telah dan majemen usaha sederhana, dimasak merupakan sumber vitamin A, diharapkan dapat membantu untuk B komplek dan vitamin C. Kandungan meningkatkan penghasilan para mineral Ca dan P pada buah sukun lebih anggota kelompok. Selain itu, baik daripada kandungan zat tersebut diharapkan dapat menambah lapangan pada kentang, diperkirakan hampir pekerjaan bagi masyarakat sekitar sama dengan yang ada dalam ubi jalar untuk terlibat dalam proses pengolahan (Suprapti, 2002). buah sukun.

Di Pedukuhan Klajuran Rt 07 Rw 03, Desa Tanjungharjo terdapat METODE / APLIKASI kelompok ibu-ibu PKK dengan jumlah anggota yang tergabung mencapai 25 orang anggota aktif. Kelompok ini biasanya hanya mengolah buah sukun dengan cara cara digoreng atau direbus, tidak ada cara-cara pengolahan lain. Salah satu faktor yang menyebabkan kurangnya pengembangan dan pengolahan produk tersebut menjadi sebuah usaha bagi masyarakat adalah, karena minimnya pengetahuan tentang berbagai macam cara pengolahan, teknologi pengemasan dan manajemen usaha yang masih sangat sederhana dan kurang menarik.

Dengan diadakannya penyuluhan dan pelatihan pengolahan kue donat dari buah sukun, pelatihan pengemasan

Pelaksanaan kegiatan pengabdian masyarakat ini direncanakan dibagi dalam tiga tahap kegiatan yaitu :

\section{Tahap Koordinasi dan Persiapan} Alat dan Bahan.

Tahap ini meliputi beberapa langkah yaitu :

a. Koordinasi dengan Ketua ibuibu PKK serta pengurusan perijinan kegiatan.

b. Persiapan materi pelatihan sesuai jenis ipteks yang akan diterapkan.

\section{Tahapan Penerapan IPTEKS}

\section{a. Pemberian Penyuluhan}

Materi penyuluhan yang diberikan meliputi : 
1) Jenis-jenis dan prinsip dasar kemasan

pangan.

Disampaikan oleh Agus

Setiyoko, S.TP.,M.Sc. Tujuan penyuluhan ini adalah memberikan informasi dan pengetahuan kepada masyarakat tentang jenisjenis kemasan, keunggulan dan kelemahan tiap jenis kemasan, serta cara pengemasan yang baik dan menarik bagi konsumen. Harapan dari penyuluahn ini adalah akan meningkatkan mutu dari kemasan produk pangan, sehingga lebih diperhatikan konsumen serta meningkatkan minat konsumen untuk membelinya.

2) Manajemen usaha sederhana. Disampaikan oleh Agus Slamet, S.TP.,MP. Tujuan pelatihan manajemen keuangan ini adalah untuk menjaga sistem keuangan dan arus

\begin{abstract}
keuangan usaha berjalan lancar, membantu kelompok ibu-ibu PKK dalam melakukan pembukuan keuangan secara tertib dan rapi. Dengan adanya kegiatan pembukuan tersebut, ibu-ibu PKK dapat menyajikan informasi keuangan usaha secara akurat, meliputi penghitungan biaya produksi penghitungan laba rugi, menentukan harga jual, serta efisiensi dalam proses produksi.
\end{abstract}

\section{b. Pelatihan}

Pelatihan dilaksanakan dengan melibatkan seluruh peserta, dibagi menjadi dua kelompok. Pelatihan ini dilakukan sampai semua peserta mampu mempraktekkan sendiri.

HASIL, PEMBAHASAN DAN DAMPAK

Pengabdian kepada masyarakat dengan judul Pengembangan Pangan Lokal Melalui Pembuatan "Dokun" (Donat 
Sukun) Aneka Toping Di Klajuran, Desa

Tanjungharjo, Nanggulan, Kulonprogo ini dilaksankan di rumah Kepala Dukuh Rt 07 Rw 03 Klajuran, Tanjungharjo, Nanggulan, Kulonprogo. Adapun kegiatan-kegiatan yang dilakukan adalah sebagai berikut :

\section{A. Tahap Koordinasi dan Persiapan} Alat dan Bahan.

1. Pada tahap koordinasi dan persiapan dilaksanakan observasi dan permohonan ijin ke tempat tujuan guna mendapatkan ijin untuk melaksanakan kegiatan pelatihan, sekaligus mencari informasi jumlah peserta yang akan dilibatkan dalam kegiatan tersebut.

2. Sosialisasi akan diadakannya kegiatan pengabdian pada kelompok oleh tim pengabdian, dimana waktu pelaksanaan diambil menyesuaikan dengan kesediaan ibu-ibu untuk berkumpul mengikuti pelatihan,

3. Peninjauan tempat untuk kegiatan penyuluhan kepada mitra pengabdian yang berlokasi di rumah kepala dukuh Klajuran Rt 07 Rw 05, Tanjungharjo, Nanggulan, Kulonprogo, yaitu survey tempat dilaksanakannya pelatihan, jumlah peserta dan membagi peserta menjadi beberapa kelompok kerja ketika pelatihan, penyusunan bahan dan alat pelatihan, merancang alat evaluasi produk terkait tanggapan peserta.

4. Mempersiapkan kegiatan penyuluhan dan pelatihan kepada mitra pengabdian tentang produk olahan dari buah sukun berupa donat sukun. Persiapan kegiatan ini berupa penentuan formulasi pembuatan donat sukun aneka toping, pembuatan modul penyuluhan dan pelatihan. Modul penyuluhan berisi materi dasar tentang jenis-jenis kemasan dan prinsip pengemasan pangan, dan manajemen keuangan 
sederhana. Modul pelatihan berisi tentang bahan-bahan, alat-alat dan cara pembuatan donat sukun. Tim pengabdian melakukan uji coba resep pembuatan produk donat sukun aneka toping, sehingga didapatkan komposisi yang tepat dan memberikan hasil sesuai harapan.

Formulasi donat sukun yang diperoleh sebagai berikut:
a. Terigu Cakra kembar (350 gram)
b. Tepung Sukun (150 gram)
C. Fermipan/ragi instan (6 gram)
d. Air Es (200 gram)
e. Gula (90 gram)
f. Garam (5 gram)
g. Margarine (30 gram)
h. Butter Oil Substitute (BOS) (25 gram)

i. Susu cair (65 gram)

j. Kuning Telur (3 buah)

k. Baking powder (1,5 gram)

I. Aneka toping (sesuai selera)

Cara membuat donat sukun aneka toping sebagi berikut :
1. Gula pasir dan margarine di mixer dengan kecepatan rendah hingga menyatu.

2. Tambahkan fermipan, baking powder, kuning telur dan Butter Oil Substitute (BOS) secara bertahap dan di mixer dengan kecepatan sedang hingga adonan menyatu.

3. Tambahkan tepung cakra dan tepung sukun yang telah dicampur dan air es ke dalam adonan sedikit demi sedikit hingga adonan kalis.

4. Istirahatkan dan tutup dengan plastik selama10 menit.

5. Rol adonan hingga ketebalan 15 $\mathrm{mm}$ dan cetak menggunakan cetakan donat.

6. Susun adonan di loyang yang telah di olesi margarin.

7. Tutup dengan kain yang telah dibasahi dan istirahatkan selama 30-40 menit.

8. Goreng adonan dengan api sedang hingga donat berwarna kuning keemasan. Angkat dan tiriskan. 
9. Oles dengan mentega dan taburi dengan bahan topping sesuai selera

B. Melaksanakan

kegiatan penyuluhan dan pelatihan:

a. Penyuluhan diadakan dirumah kepala dukuh Klajuran dengan dihadiri oleh ibu-ibu PKK mitra. Penyuluhan dilaksanakan hari Minggu, 23 Juli 2017. Materi yang disampaikan adalah: penyuluh tentang jenis-jenis kemasan dan prinsip dasar kemasan pangan (Agus Setiyoko, S.TP.,M.Sc) dan penyuluh tentang manajemen keuangan sederhana (Agus Slamet, S.TP.,MP)
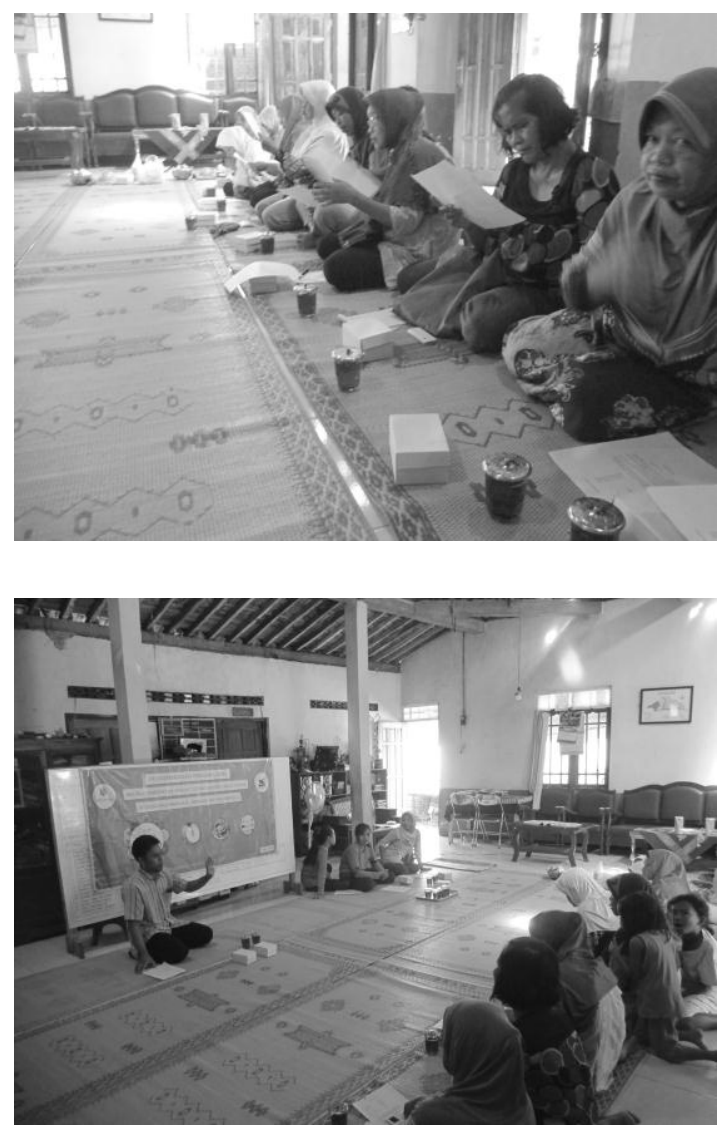

Gambar 1. Peserta Penyuluhan dan Pelatihan 
b. Praktek pengolahan sukun menjadi donat sukun aneka toping:

Pelatihan diawali dengan pemberian materi sebelum pelatihan dengan tujuan memberikan gambaran serta keterampilan kepada masyarakat tentang pengolahan donat sederhana, faktor-faktor penting yang harus diperhatikan, resep pembuatan donat sederhana, serta cara menghasilkan donat yang empuk dan lembut agar disukai oleh para konsumen. Pelatiahn tersebut disampaikan dengan cara presentasi didepan peserta yang dilanjutkan dengan tanya jawab seputar donat. Setelah pemberian materi selesai, dilanjutkan dengan praktek secara langsung pembuatan donat sukun aneka toping. Pelatihan dilaksanakan dengan melibatkan seluruh peserta, dibagi menjadi dua kelompok. Pelatihan ini dilakukan sampai semua peserta mampu mempraktekkan sendiri.

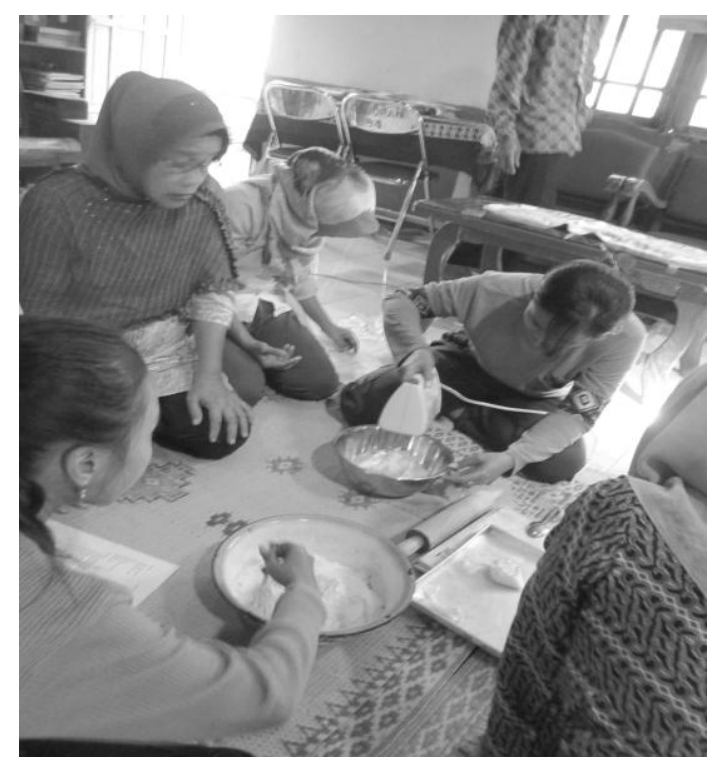

Gambar 3. Kelompok 1

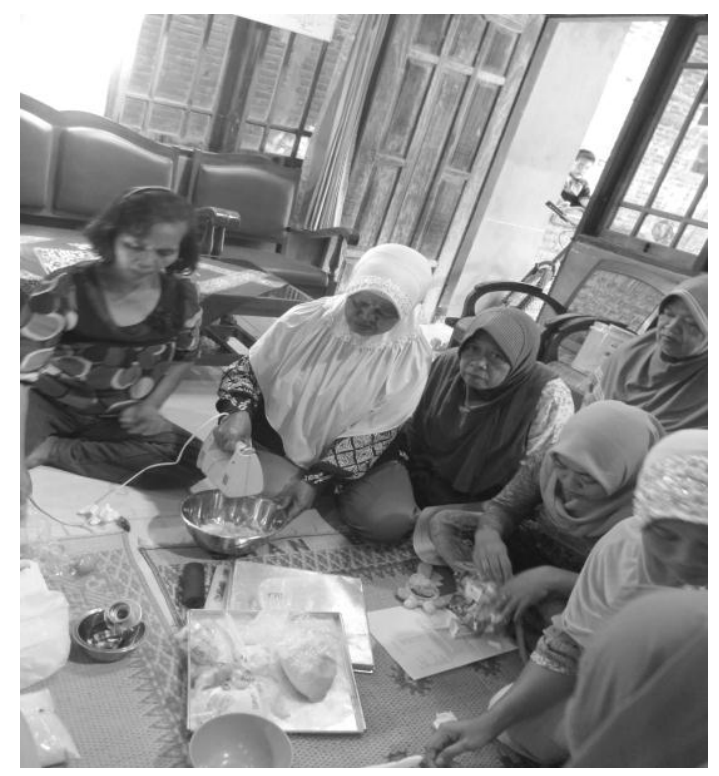

Gambar 4. Kelompok 2 
Jurnal SEMAR, ISSN 2302-3937

Vol.6 No.1 Nopember 2017

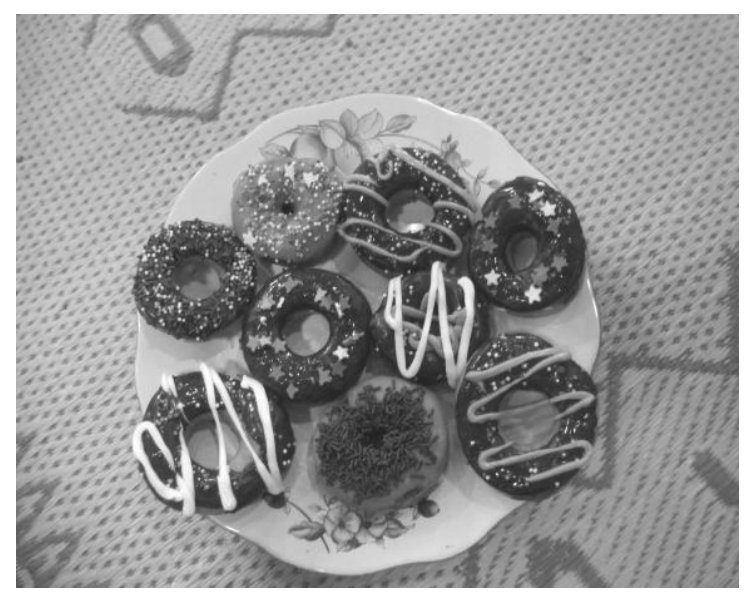

Gambar 5. Donat sukun aneka topping

kelompok 1

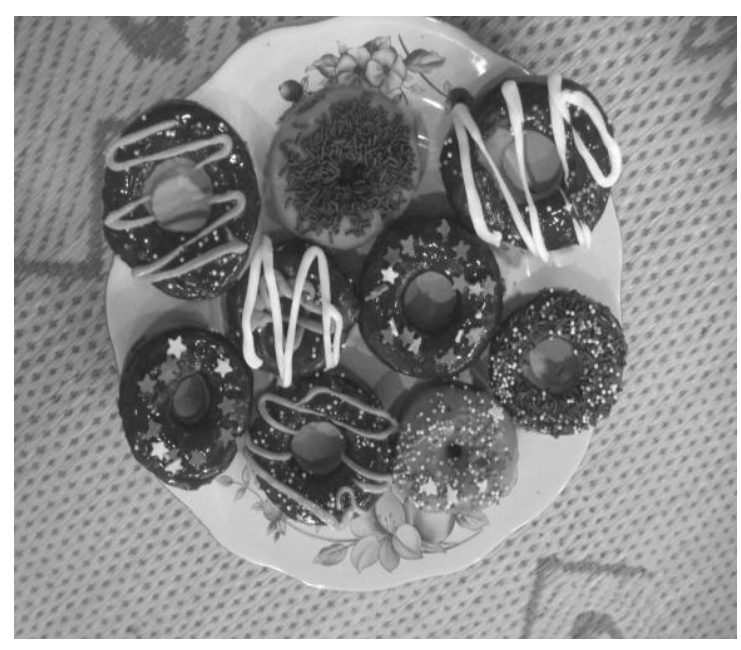

Gambar 6. Donat sukun aneka topping

kelompok 2 
Dampak adanya kegiatan penyuluhan dan pelatihan pengolahan donat sukun ini adalah: buah sukun dapat menjadi makanan yang digemari oleh semua kalangan dari anak-anak hingga dewasa, adanya diversifikasi olahan dari buah sukun, adanya manajemen keuangan dan pembukuan secara sederhana agar setiap transaksi tercatat dengan baik dan rapi. Membuka lapangan kerja baru dan tentunya memperbaiki kondisi ekonomi dan kesejahteraan masyarakat.

\section{Evaluasi dan Tindak Lanjut}

Setelah kegiatan penyuluhan tentang jenis-jenis kemasan dan manajemen usaha sederhana serta pelatihan pengolahan sukun menjadi donat sukun aneka toping dilakukan maka tahapan yang selanjutnya adalah :

1. Evaluasi pengetahuan (materi teori) penyuluhan dengan alat bantu borang kuisioner untuk mengetahui kepemahaman peserta tentang materi penyuluhan yang telah disampaikan. Hasil borang evaluasi menunjukkan bahwa peserta sangat senang dengan kegiatan pengabdian in, karena mitra belum pernah mendapatkan penyuluhan dan pelatihan tentang jenis-jenis pengemas dan prinsip pengemasan pangan, manajemen usaha sederhana, serta pelatihan donat sukun aneka toping. Menurut pserta, isi materi penyuluhan dan pelatihan yang diberikan mudah dimengerti dan mudah dipraktekan sendiri, bahan dan alat dalam pembuatan donat sukun aneka toping mudah didapatkan, waktu pelaksanaan kegiatan tidak mengganggu aktivitas bekerja. Disamping itu peserta juga termotivasi dan tertarik untuk mengembangkan lebih lanjut sehingga dapat berwirausaha mandiri.

2. Evaluasi praktik dengan cara mengadakan lomba membuat aneka kreasi olahan donat berbahan baku buah sukun. Penilaian didasarkan pada seberapa banyak donat sukun yang 
disukai oleh anak-anak yang dihadirkan sejumlah 20 orang. Dari hasil perhitungan diperolehlah pemenang kelompok 1 dengan jumlah donat yang dipilih dan disukai anak-anak sebanyak 30 buah.

\section{PENUTUP}

Berdasarkan hasil evaluasi pelaksanaan kegiatan pengabdian, dapat disimpulkan sebagai berikut:

1. Kegiatan pengabdian dan pelatihan berjalan lacar, sesuai rencana, dan memperoleh sambutan yang baik dari masyarakat

2. Adanya manajemen keuangan dan pembukuan secara sederhana, sehingga setiap transaksi tercatat dengan baik dan rapi

3. Masyarakat memperoleh keterampilan baru dalam hal diversifikasi pengolahan buah sukun, salah satunya diolah menjadi donat sukun aneka toping

4. Membuka peluang usaha baru, dalam rangka meningkatkan taraf ekonomi masyarakat

\section{UCAPAN TERIMAKASIH}

Ucapan terima kasih kami sampaikan sebear - besarnya kepada:

1. Rektor UMBY atas bantuan dana pengabdian masyarakat ini melalui skim LPPM, sehingga kegiatan ini dapat berjalan dan terselesaikan dengan tepat waktu.

2. Ketua LPPM UMBY, selaku pihak yang telah memfasilitasi, mulai dari pengajuan proposal sampai laporan kegiatan ini selesai.

3. Dekan Fakultas Agroindustri UMBY, atas persetujuan Beliau kegiatan pengabdian ini dapat dilakukan.

4. Ibu-Ibu PKK klajuran yang selalu bersemangat dan antusias mengikuti pengabdian dan pelatihan ini. 


\section{DAFTAR PUSTAKA}

BPS, 2016. Kabupaten Kulon Progo

dalam Angka. BPS Kabupaten Kulon

Progo.

Djafaar, T.F. 2004. Sukun Cilacap yang

Lebih Menguntungkan. BPTP

Yogyakarta.

Suprapti, M. L. 2002. Tepung Sukun, Pembuatan dan Pemanfaatan.

Kanisius, Yogyakarta. 


\section{BIODATA PENELITI}

\section{Agus Setiyoko, S.TP., M.Sc.}

Tenaga kependidikan Universitas Mercu Buana Yogyakarta. Lahir di Kabupaten Semarang pada 13 Agustus 1990. Saat ini menjabat sebagai Wakil Direktur Bidang Akademik dan kemahasiswaan Universitas Mercu Buana Yogyakarta. Pendidikan terakhir adalah magister (S2) di bidang Ilmu dan Teknologi Pangan Universitas Mercu Buana Yogyakarta. Pengalaman penelitian dan pengabdian pada masyarakat diantaranya Pengembangan Pangan Lokal Melalui Pembuatan "Dokun" (Donat Sukun) Aneka Toping di Desa Tanjungharjo, Nanggulan, Kulon Progo. 